\section{Successful aggression as the reinforcer for runway behavior of mice*}

\author{
ROSS LEGRAND \\ St. Olaf College, Northfield, Minn. 55057
}

Male mice graded for aggressiveness ran in a runway for the opportunity to defeat submissive mice as a reinforcer on $0 \%, 50 \%$, and $100 \%$ reinforcement schedules. Half the Ss were given a brief fight immediately before each trial. Reinforcement schedules produced effects analogous to those found with traditional reinforcers. Both the prefight manipulation and high ratings on aggressiveness were found to facilitate running behavior in general, but they did not interact with the schedules of reinforcement.

The intraspecific aggression of mice has been demonstrated to serve as a reinforcer for instrumental behavior in a T-maze (Tellegen, Horn, \& Legrand, 1969). The purpose of the present study was to investigate in a runway situation three other aspects of this reinforcer. It was of interest to know whether or not schedules of reinforcement could be manipulated with results analogous to those found with traditional reinforcers. Specifically, would it be possible to produce a partial reinforcement effect in extinction: that is, slower extinction for a group reinforced on onehalf the acquisition trials than for a group reinforced on every acquisition trial? A second question involved the effect of aggressive arousal on behavior instrumental to aggression as a reinforcer. Lagerspetz (1964) concluded from her studies of mice in a runway situation that the opportunity for aggression in the goalbox served as a reinforcer only when it was preceded by a brief fight in the startbox. However, her lack of a control group given a prefight but made to run to an empty goalbox left open the question of whether a prefight facilitates only that running that leads to a resumption of fighting or whether it facilitates running in general. A related question involved the role of individual differences in aggressiveness. Is fighting a more effective reinforcer in mice that have been assessed as aggressive than in less aggressive mice? Lagerspetz found an aggressive strain of mice was more active than a nonaggressive strain, but in her study only aggressive mice were made to run to a successful fight, and, therefore, she did not resolve the problem of whether high aggressiveness facilitates only that running that leads to a fight or all running.

The present study used trained fighters

*This research was in partial fulfillment of the requirements for the $\mathrm{PhD}$ degree and was supported by a grant to Dr. Auke Tellegen from the graduate school of the University of Minnesota. of their aggression by three raters

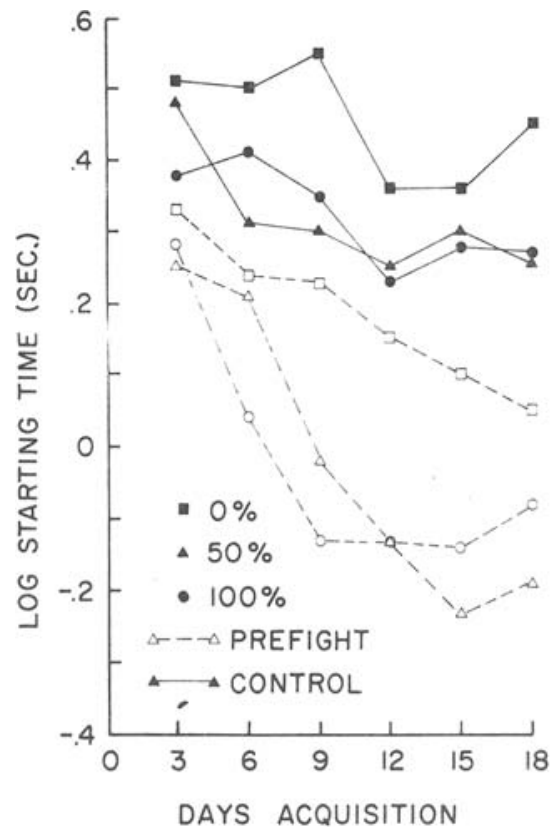

experienced in observing combat between mice. A simple summed rating allowed $E$ to divide the sample equally into good and poor fighters. On the last 2 days of training, each $\mathrm{S}$ was allowed to explore the runway apparatus for $2 \mathrm{~min}$ or until it had traversed the runway at least once.

The apparatus was a straight alley runway $40 \mathrm{in}$. long from startbox to goalbox, $4 \mathrm{in}$. wide, $4 \mathrm{in}$. high, and covered by $1 / 4$-in. wire mesh. The startbox was $7 \times 5 \times 9$ in. and had an opaque lid. Raising a guillotine door admitted $S$ from the startbox into the alley and started a Knight photoelectric relay located $6 \mathrm{in}$. beyond the door. When $S$ passed the relay, a Standard timer stopped, giving a measure of starting time, and a second timer began that stopped when $S$ passed a second relay located 3 in. before the goalbox, giving a measure of running time. Barriers set 1 in. from the floor over each relay forced $S$ to crouch and insured that the relays would be tripped. Guillotine doors were located $6 \mathrm{in}$. before the second relay and at the entrance of the goalbox. All doors were closed after $S$ passed in order to prevent retracing. The goalbox was $7 \times 6 \frac{1}{2} \times 13 \frac{1}{2}$ in. A partition could be lowered to close off the 4 in. of its length furthest from the entrance in order to conceal the presence or absence of reinforcement. The entire apparatus was painted flat black.

The Ss were assigned randomly to $0 \%$, $50 \%$, and $100 \%$ reinforcement schedule groups and to prefight and control conditions with the constraint that each cell contain an equal number of good and

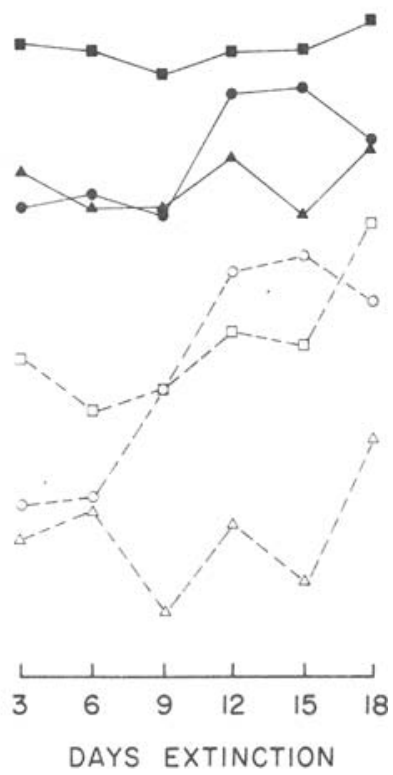

Fig. 1. Starting time means in blocks of 3 days for acquisition and extinction. 

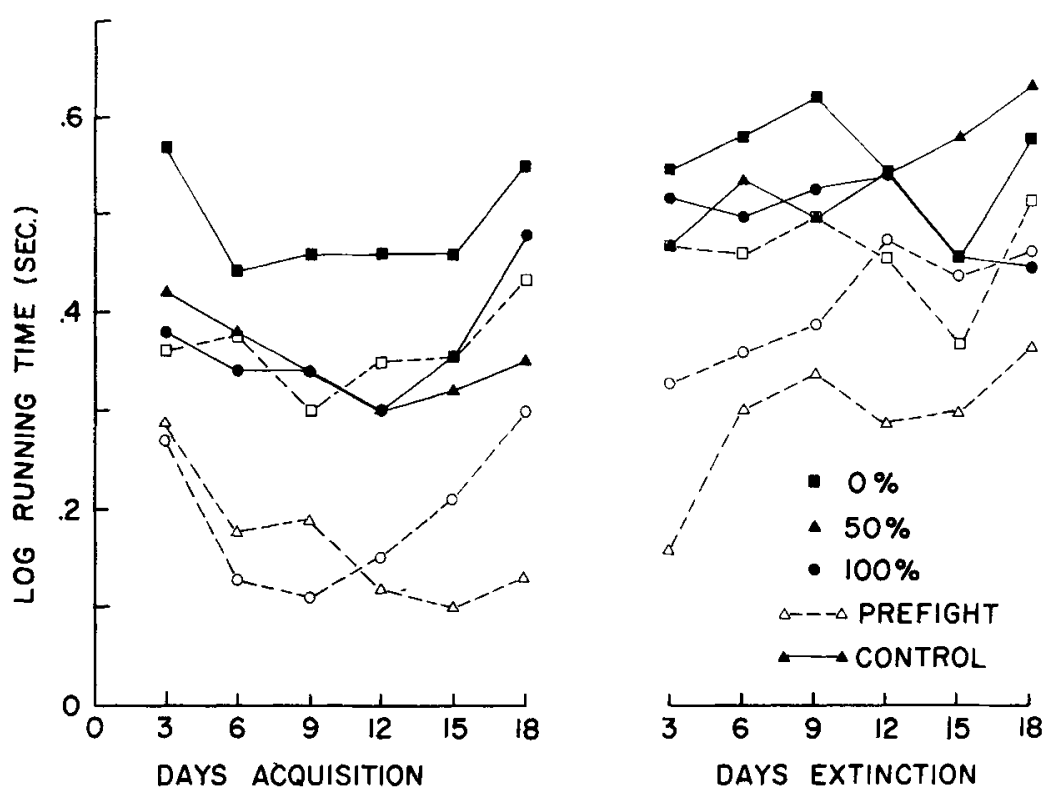

Fig. 2. Running time means in blocks of 3 days for acquisition and extinction.

poor fighters. Ss were assigned randomly to units of eight and the order in which these units were run was randomized from day to day. During acquisition each $S$ was administered four trials per day in the runway with an intertrial interval of approximately $5 \mathrm{~min}$. Ss in the prefight condition were placed in the startbox and allowed to attack a helpless, dangled victim for $5 \mathrm{sec}$. The lid was then closed and a 2-sec delay elapsed before the guillotine door was raised to start the trial. Ss in the control condition were simply given a $2-\mathrm{sec}$ delay.

On reinforced trials the goalbox partition was raised to reveal a victim, and $S$ was allowed to attack and pursue the victim for $5 \mathrm{sec}$ before the victim was removed. $\mathrm{S}$ was then allowed to explore the empty goalbox for $10 \mathrm{sec}$ before being returned to its cage. On nonreinforced trials the victim was removed from the goalbox after $S$ had entered and immediately before the partition was raised. $S$ was then allowed to explore the empty goalbox for $15 \mathrm{sec}$ before its removal. Ss in the partial reinforcement group received two reinforced and two nonreinforced trials each day in random patterns. Acquisition was continued for 18 days, at which point all groups had maintained asymptote for several days. The procedure for the 18 days of extinction was the same as that for the nonreinforced trials during acquisition.

In order that all Ss would experience an equal number of fights each day and thus maintain their aggressiveness at a stable level, supplementary fights were given to those Ss that had not had the maximum
1-18, $\quad F=3.03, \quad \mathrm{df}=2 / 36, \quad \mathrm{p}<.10$ ). It should be noted that starting times showed more variability than running times during both acquisition and extinction.

The effect of aggression as a reinforcer was also found in a significant Trials by Reinforcement Schedules interaction late in acquisition for running times (Days $13-18, F=3.68$, df $=6 / 108, p<.01$ ). This interaction was due to a differential warmup effect, as the reinforced groups showed a decrease in running times on later trials each day, whereas the $0 \%$ groups showed an increase.

No significant reinforcement schedule effects were found for Days 2-6 of extinction. However, despite the weak evidence for a reinforcement effect on starting times during acquisition, for Days 13-18 of extinction, a linear contrast between starting times for the $50 \%$ and $100 \%$ groups revealed a trend in the direction of a partial reinforcement effect that just failed to reach significance at the .05 level $(F=4.14$, df $=1 / 36, p<.10)$. It can be hypothesized that more competing responses were available in the start box than in the alley, which made it difficult to obtain a reinforcement effect for starting times during acquisition, yet which facilitated the appearance of a partial reinforcement effect during extinction.

The prefight group started faster and ran faster than the control group in both acquisition (Days 1-18, $F=23.08$, $\mathrm{df}=1 / 36, \quad \mathrm{p}<.001$, and $\mathrm{F}=14.98$, $\mathrm{df}=1 / 36, \quad \mathrm{p}<.001, \quad$ respectively) and extinction (Days 1-18, $F=27.03$, $\mathrm{df}=1 / 36, \quad \mathrm{p}<.001, \quad$ and $\mathrm{F}=6.75$, $\mathrm{df}=1 / 36, \mathrm{p}<.025$, respectively). Ss rated as good fighters were faster on both variables than poor fighters in acquisition (Days $1-18, F=7.02, d f=1 / 36, p<.025$, $\mathrm{F}=8.65, \mathrm{df}=1 / 36, \mathrm{p}<.01$, respectively) and in extinction (Days $1-18, F=6.81$, $\mathrm{df}=1 / 36, \quad \mathrm{p}<.025$, and $\mathrm{F}=4.24$, $\mathrm{df}=1 / 36, \mathrm{p}<.05$, respectively). Neither prefight nor aggressiveness interacted with the schedules of reinforcement.

\section{DISCUSSION}

The opportunity for successful aggression served as a reinforcer for runway behavior of mice in a manner analogous to traditional reinforcers, as shown by the superior performance of the reinforced groups as compared to the nonreinforced groups. Evidence for a partial reinforcement effect in extinction fell just short of the .05 level of significance. Amsel (1962) has attributed this effect to the conditioning of frustration to the cues of running to the goalbox under partial reinforcement conditions. Other invastigators have demonstrated that techniques designed to produce frustration can elicit aggressive behavior in both 
discrete-trial (Gallup, 1965) and continuous-trial situations (Azrin, Hutchinson, \& Hake, 1966; Davis \& Denenfeld, 1967; Thompson \& Bloom, 1966). The partial reinforcement data from the present study can only weakly suggest that the experimental manipulations for frustration and aggression produce distinctive cues for these mice. In Amsel's terms, this means that anticipatory frustration and anticipatory aggression may both develop during acquisition in a study of aggression and may be sufficiently distinct to permit some partial reinforcement effect during extinction.

The prefight manipulation proved to be the most powerful one in this study. Examination of the graphs reveals that mice which received a prefight but no reinforcement started faster and ran as fast as reinforced mice that were not given a prefight. Contrary to Lagerspetz's hypothesis, this variable did not interact with the schedules of reinforcement. The prefight served to facilitate runway behavior in general rather than to selectively facilitate those running responses which led to a successful fight. High aggressiveness served in a similar manner. In other words, neither aggressive arousal nor a high level of aggressiveness served to make a successful fight more reinforcing for these mice, but both were general facilitators of running behavior.

\section{REFERENCES}

AMSEL, A. Frustrative nonreward in partial reinforcement and discrimination learning Some recent history and a theoretical extension. Psychological Review, 1962, 69, 306-328.

AZRIN, N. H., HUTCHINSON, R. R., \& HAKE, D. F. Extinction-induced aggression. Journal of the Expeximental Analysis of Behavior, 1966, 9, 191-204.

DAVIS, H. \& DENENFELD, I Extinction-induced social interaction in rats. Psychonomic Scicrse, 1967, 7, 85-86.

GALLUP, G. G. Aggression in rats as a function of frustrative nonreward in a straight alley. Psychonomic Science, 1965, 3, 99-100.

LAGERSPETZ, K. Studies on the aggressive behavior of mice. Helsinki: Suomalainen Tiedeakatemia, 1964.

TELLEGEN, A., HORN, J. M., \& LEGRAND, R. G. Opportunity for aggression as a reinfoicer in mice. Psychonomic Science, 1969, 14, 104-105.

THOMPSON, T., \& BLOOM, W. Aggressive behavior and extinction-induced response-sate increase. Psychonomic Science, 1966, 5, 335-336.

\section{Escape thresholds to electric shock using a conditioned pole-displacement response in rats*}

\author{
GORDON T, PRYOR \\ Stanford Research Institute, Menlo Park, Calif. 94025
}

Rats were first taught to displace a pole in order to escape a 1.0-mA shock to the feet. During a subsequent test session, 60 random presentations of several intensities of shock were used to generate psychophysical response curves and estimate escape thresholds. The median escape threshold for 48 rats was $0.18 \mathrm{~mA}$ using this procedure. The results are compared to other threshold procedures designed to assess the aversiveness of electric shock.

Electric shock is widely used as an aversive stimulus in behavioral research. Three main procedures and variations thereon have been used to assess the aversiveness or motivating strength of shock stimuli. Campbell \& Teghtsoonian (1958) defined an aversion threshold as the intensity of shock that rats would avoid $75 \%$ of the time in a spatial preference. Weiss \& Laties (1961) used a titration procedure in which the rat pressed a lever to reduce the intensity of shock on the floor; the intensity was programmed to increase in discrete steps at regular intervals, and the threshold was taken as the median intensity at which the shock was maintained. Finally, Evans (196I)

*This research was supported by Contract Noni-2993(00) between the U.S. Office of Naval Rescarch and Stanford Research Institute. itself (e.g., Misanin \& Campbell, 1969; Paré, 1969; Blanchard \& Blanchard, 1966).

This report describes a procedure for investigating the rat's aversion to shock in which the response is displacing a pole on discrete trials to escape and terminate the stimulus. The procedure evolved from a number of other studies in which conditioned avoidance was being investigated using shock as the unconditioned stimulus. It was considered important to establish escape response curves as a function of intensity as a baseline for these other studies. The procedure, however, is considered to possess utility in its own right for studies dealing with the aversiveness of electric shock and agents that may infuence the rat's response to this stimulus.

\section{APPARATUS}

A wooden chamber measuring $12 \times 14 \times 16$ in., painted flat gray, was used. The gijil floor consisted of 1/8-in.-diam brass rods spaced $1 / 2 \mathrm{in.}$ apart. A $7 \frac{1}{2} \cdot$ W lamp and loudspeaker were mounted in the ceiling. A 1/2-in.-diam pole suspended from the center of the ceiling served as the manipulandum. Displacing the pole $1 / 16$ in. closed a microswitch that signaled a response. The chamber was located in a $14 \times 20 \times 32$ in. ventilated, light-tight, sound-attenuated cubicie. Twelve such units were interfaced with a Digital Equipment Corporation PDP-8/S computer located in an adjoining room for automatic control and data collection. The hardware and software for this system allowed up to eight units to operate simultaneously on a given trial (Pryor, Otis, \& Willis, 1969). The shock source supplied supplied a biphasic square wave scrambled among four bars, each pulse lasting $16 \mathrm{msec}$, with an interpulse interval of 0 , 16 , or $32 \mathrm{msec}$. The output impedance of the active current source to each bar was greater than 50 megohms, with a voltage compliance of $250 \mathrm{~V}$.

\section{SUBJECTS AND PROCEDURE}

Seventy-two naive male rats of the Long-Evans strain, obtained from Simonsen Laboratories (Giliroy, California) and weighing on the average $359 \mathrm{~g}$, were used. They were housed four to a cage, with food and water ad lib, for at least 2 weeks prior to the experiment. On Days 1 and 2, all animals were given 30 trials in which they learned to displace an 8-in. pole to escape and terminate a $1-\mathrm{mA}$ shock that remained on the grill floor for a maximum of $30 \mathrm{sec}$. Trials were presented randomily in time, with an average intertrial interval of $2.5 \mathrm{~min}$. The pole was lubricated before each session with Dow-Corning Stopcock grease to discourage the rat from climbing up and hanging onto the pole. On Day 3 , 60 trials were given to stabilize 